\title{
Promoting language learning: The use of mLearning in the Spanish classes
}

\author{
Glenda Mejía ${ }^{1}$ \\ RMIT University
}

\begin{abstract}
The aim of this study is to investigate the benefits of integrating Mobile Learning (mLearning) into language teaching activities to promote active student engagement and independent learning. A total of 72 beginner level students of Spanish (European Framework: A1.1 (Spanish 1) and A1.2 (Spanish 2) participated in this study. This project was undertaken between Sem II 2014 and Sem I 2015 with the participation of RMIT students from a variety of degree backgrounds: Media, International studies, Business, Music, Engineering, Animation, Education, Social Work and Photography. The study took into consideration pedagogical principles, mobile principles, and blended methods, and the learning outcomes of each course: RMIT graduate attributes were also considered. As part of their assessment students were asked to produce a socio-cultural video using mobile phones, iPads, video cameras or other such devices. The practice of employing methods of qualitative data collection (on-line survey, interviews, observations and video samples) resulted in a demonstrable improvement in oral skills, vocabulary and grammar, while at the same time allowing students to be creative with the use of technological devices. Based on the results, this study provides insights into students' and teachers' views on the benefits of using mLearning for Spanish language learning. Unfortunately, their feedback was negative in terms of technology support from the University. It is, however hoped that the findings of the study will motivate other language educators to use mLearning activities to evaluate learners' oral skills.
\end{abstract}

Keywords: Spanish learning; mLearning; smartphones; oral skills

Corresponding author - RMIT University, School of Global, Urban and Social Studies Melbourne (Australia).Email: glenda.mejia@rmit.edu.au 


\section{Resumen}

Este estudio tiene como objetivo investigar los beneficios de la integración de Mobile Learning (mLearning) en actividades de enseñanza de idiomas con la intención de promover la participación activa del alumno y su aprendizaje independiente. Un total de 72 estudiantes de español de nivel principiante (Marco europeo: A1.1 (español 1) y A1.2 (español 2)) participaron en este estudio. Este proyecto se llevó a cabo entre el primer semestre 2014 y el segundo semestre 2015, con la participación de estudiantes de la Universidad de RMIT de distintos programas: medios de comunicación, estudios internacionales, negocios, ingeniería, música, animación, educación, trabajo social y fotografía. El estudio tomó en cuenta los principios pedagógicos y los principios metodológicos del uso de los móviles. Los objetivos de aprendizaje de cada curso y los atributos de graduación de RMIT también fueron considerados. Como parte de la evaluación se pidió a los estudiantes que produjeran un vídeo de contenido socio-cultural utilizando dispositivos electrónicos como teléfonos móviles, iPads, cámaras de video. Los datos para el presente estudio se obtuvieron por medio de métodos de recolección de datos cualitativos (encuesta on-line, entrevistas, observaciones y muestras de vídeo). Los resultados mostraron una mejora en las habilidades orales, el vocabulario y la gramática de los estudiantes, al mismo tiempo que se les permite desarrollar su creatividad con el uso de dispositivos tecnológicos. En base a los resultados, este estudio aporta una visión de las opiniones de los alumnos y de los profesores sobre las ventajas de usar mLearning durante el aprendizaje del español. Lamentablemente, sus comentarios han sido negativos en lo que respecta al del soporte tecnológico de la Universidad. Por último, se espera que los hallazgos de este estudio motiven a otros educadores de idiomas a utilizar actividades de mLearning para evaluar las habilidades orales de los alumnos.

Palabras claves: aprendizaje del español; mLearning; smartphones; habilidades orales

\section{INTRODUCTION}

There is a growing body of literature regarding the uses and benefits of mLearning activities and the benefits and relevance their use might have in the process of learning a second language. For instance, the use of podcasts, iPod, QR (quick response), SMS (short message service), and blogs (e.g. Evans, 2008; Levy and Kennedy, 2005; Gromik, 2012; Gutiérrez-Colón Plana, Gimeno, Appel and Hopkins, 2015; Stockwell and Hubbard, 2013). Although the above studies mention the use of a number of mLearning activities in second language learning, few studies have explored the use of smartphones to record videos. One such case is Gromiks's (2012) study of Japanese students learning English as a Foreign Language (EFL) where cell phones were used for video recording. Hence, this study focuses on smartphone activities completed outside the classroom as a form of an assessment, and the benefits that these might bring to the process of second language learning.

Most studies on the use of technology-assisted second language learning point out the benefits of incorporating technology-based activities in the EFL class. 
For instance, Tozcu's (2008) study on teaching non-Latin based orthographies such as Hindi, Pashto, Dari, Persian (Farsi), and Hebrew, show that the use of interactive white boards increases students' enthusiasm and engagement in the learning process. Similarly, Sykes (2005) found that the use of text chat by Spanish learners helped them to produce complex written structures; and Chang, Wu and Ku (2004) in their study in Taiwan found that that the use of tablets for reading activities tended to reduce student anxiety, "promote motivation to learn, and enhance oral reading confidence" (p. 142). There are also other scholars from the Spanish world who have used technology in the design of activities in their classes and have stated the benefits of its use (e.g. Losada, 2005; Navarro Andrés, 2013 and Bastarrechea, 2003). However, there is relatively little research that focuses on the benefits of smartphones in the second language learning process, either from the student point of view or from the teacher's as facilitator. This study then, recognizes the importance of listening to student feedback with regard to the advantages and disadvantages of mLearning, in this case, smartphones. In so doing modifications can be made and put it into practice in teaching activities with the aim of incorporating more smartphone activities in class.

It is not within the scope of this article to discuss in depth the drawbacks of using mLearning, but it is important to mention that not all scholars are convinced the use of mLearning is beneficial to students and teachers. Some of the major concerns are the creation of new software tools (Kadirire, 2009); the cost for students and institutions (Ally, 2013); the lack of and/or inappropriate training for teachers (Ally, 2013); and the lack of communication and collaboration between students, as found by Dieterle, Dede and Schrier (2007) in their studies of English language learners.

The purpose of this article is to contribute to the field of existing research on language learning by describing the benefits that students claim to derive from the use of mobile devices in their Spanish assessment, bearing in mind that technology is merely an adjunct to pedagogy. In Picciano's (2016) words "when it comes to teaching and learning it is the pedagogy that should drive technology and not the other way around" (p. 3). The author of this article believes in providing a supportive environment for learning to take place, that is, one that is student-centred with the teacher as the facilitator, where there is a belief in co-learning and co-creating, and where students feel challenged, but where their imagination and creativity are fostered.

These conditions, in conjunction with the use of mLearning activities, should increase the opportunities for students to hone their oral skills in the target language. Therefore, it is expected that the use of mobile phone assessments 
in this study will allow students to develop oral proficiency and to perceive the benefits in the learning process. This study also aims to discover what benefits teachers see in the of use of mLearning activities and whether as a result they might later on contribute effectively to the development of the Spanish curriculum by incorporating mLearning devices.

\section{BLENDED METHODS AND PEDAGOGICAL METHODS}

Nowadays, most teachers prefer to use the blended learning approach that integrates electronic devices and face-to-face delivery. This approach includes diverse activities targeting the four micro-skills: reading, writing, listening and speaking. As Stead (2005) states "the question in no longer whether m-learning works for hard-to-hard learners, but rather how best to fit it into your blend" (p.1). Garrison and Vaughan (2008) define blended learning as "a design approach whereby both face-to face and online learning are made better by the presence of the other" (p. 5). At no moment do they suggest that one should replace the other, but rather that they should complement each other. As Picciano (2009), the author of this article also believes that "a major benefit of multiple modalities is that they allow students to experience learning in ways in which they are most comfortable while also challenging them to experience and learn in other ways as well." (p. 7). Keeping in mind the benefits of using the blended method in EFL, two pedagogical principles are applied based on the teacher's style, the students' needs and the type of mLearning activity. These principles are: social constructivism and situated learning. These principles are in line with the learning outcomes of each course, the graduate attributes (GA) of RMIT University and the style and philosophy the researcher's teaching.

Honebein, Duffy and Fishman (1993) propose that knowledge is constructed by an individual's prior experience and context. Thus the benefit of the social constructivism principle is that students can construct relationships between new knowledge and prior knowledge through significant learning experiences (Johnson and Johnson, 1999). Based on this principle some researchers argue that handheld electric devices will provide a tool for learners to construct knowledge through their daily activities and in a community context (Naismith, Lonsdale, Vavoula and Sharples, 2004), i.e. video recording outside of the classroom. Scholars also state that it is important to transfer that knowledge into a situation and a context to which students can relate. It is here then that we use the situated learning principle which considers the student's physical, social and cultural environment during the learning process (Naismith, Londsdale, Vavoula and Sharples, 2004). 
Sharples, Corlett and Westmancott (2002) state that: "[T]the most successful learning comes when the learner is in control of the activity, able to test ideas by performing experiments, ask questions, collaborate with other people, seek out new knowledge, and plan new actions" (p. 225). It is therefore expected that students from this study, through the use of mLearning devices, in particular smartphones, will feel in control of a particular activity and seek out new knowledge and put it into context thus empowering them to learn whenever and wherever they want.

\section{MOBILE FEATURES AND PRINCIPLES}

In order to use mLearning activities a teacher should be aware of the mobile features and the principles of how to use mobile devices, as the aim is to integrate both the pedagogical and the mobile principles, not to substitute one for the other. This will allow teachers to use effective learning and teaching strategies in the use of mobile education. One of the features of mobile devices it is important to be aware of is the pull and push mechanism (Stockwell, 2013). The pull mechanism refers to the type of learning in which learners access learning material such as blackboard (Motiwalla, 2007). The push mechanism 'pushes' information onto the learners (Stockwell and Hubbard, 2013). For instance, sending an SMS (Short Message System see Levy and Kennedy, 2005), WhatsApp (see Gutiérrez-Colón Plana, Gimeno, Appel and Hopkins, 2015), and video recordings (see Gromik, 2012), the latter is an activity that students from this study will develop. Apart from these two features, it is also important to be aware of the why, the who and the how in the use mobile devices and what type of activities can be created as not all activities will fit into a mLearning form. Also, two important concepts of which teachers and students should be aware and should discuss when using mLearning activities are 'Digital Natives' and 'Digital Immigrants' (Prensky, 2001). The last concept was renamed 'Digital Wisdom' by Prensky (2009) after criticism from other researchers who argued that neither age nor gender determines who is more knowledgeable in the use of mobile devices. The idea that 'digital natives' are the new generation of young people who have grown up using technology and the internet and are more adept than the older generation who became acquainted with technology later in life, is not always the case as argued by Bennet, Maton and Kervin (2008) as well as Williamson and Hague (2009). Therefore, teachers or facilitators who elect to use mLearning activities cannot assume that all students are familiar with technology and its uses; nor can we assume that even though students may use technology it does not necessarily mean that they can translate that same 
knowledge into an assessment. This is why it is important for teachers to receive efficient technology training. Stockwell and Hubbard (2013) have indicated that:

an important area of consideration for any new technology implementation is the user's readiness to employ it effectively. There are two complementary areas for this view: teacher education and learner training. Teachers planning to incorporate technology into their curricula need technological pedagogical content knowledge. For language teachers, such knowledge entails both technological skills and knowledge specifically for their discipline (p. 7).

In light of this, the following research questions were formulated for this study:

1. How do students benefit from integrating mLearning into Spanish language teaching activities?

2. How might these activities motivate student engagement and independent learning?

3. How might the use of mLearning activities motivate language educators to implement these activities in their classes?

\section{THE STUDY}

\subsection{Method}

\subsubsection{Participants}

Seventy-two volunteers from three courses of 332 undergraduates and postgraduate students participated in this study. They came from different programs such as Media, International studies, Business, Music, Animation, Engineering, Education and Photography across the university in RMIT, Melbourne. Fifty-seven were female and 15 were male. Their ages ranged from 17 to 32, with an average age of 20. Participants were from different levels of Spanish. The project was carried out during two semesters. Sem II 2014: Spanish 1 (A1.1 = 109 students), Spanish 2 (A2.2 = 82 students) and Sem I 2015 Spanish 1 (A1.1 = 141 students). In reality 332 students submitted a video as part of their assessment (10\%) but not all of them participated in the survey. 


\subsubsection{Materials and apparatus}

The students were not provided with any mobile devise to produce the video. Students were given the option of using either their mobile phone or any other mobile device to complete the activity, however the researcher was hoping they would use their smartphones (iPhone, Android, Blackberry, Windows), and the majority did in Spanish 1 and 2. Most of the students from Spanish 1 and 2 had a smart phone and those who did not borrowed one from a family member. Nobody used a camera. Each video consisted of a 1 to 3 min MP3 or MP4 recording depending on their Spanish level. At the start of the project the researcher considered creating a drop box but because of limited space and the university's inability to increase it this option was eliminated. The second option was to create folders on the University's S drive but in the end this too was eliminated due to lack of access to sessional teachers. Thus, in Semester I each video was uploaded onto Google drive and in Semester II each video was uploaded onto the blackboard shell of the respective course. The aim of uploading the video onto blackboard was to have access to all the videos in one space and for the teachers to have easy access for marking.

\subsubsection{Procedure}

A research project called 'On and Off line Activities in the Spanish Classes' was conducted at RMIT University from July 2014 (Sem I) to May 2015 (Sem II). Students were provided with a clear step-by-step guide via email of how to record their video and how to submit it. This email was sent out by the researcher/coordinator to each course three times during the semester. Each teacher in each class also gave out the same information. In addition, the information was put up on each blackboard shell of each course, with a sample video of how to upload and a sample video of one of the topics "mi barrio" (my neighbourhood), which was also to be uploaded onto YouTube.

Activities were devised to allow learners to make a sociocultural video, and to facilitate oral practice, vocabulary building and sentence structure. They were required to use the vocabulary and grammar learned in the classroom from a particular unit. Spanish 1 students Sem II 2014 needed to record a selfie video, giving a brief description of their physical appearance and their personality, and their likes and dislikes. They needed to submit their video in week 10 of the semester. Spanish 2 students Sem II 2014 needed to record a video about their neighbourhood, to provide a brief description of how to get about their neighbourhood, what places were in their neighbourhood (e.g.library, bakery), descriptions of their neighbourhood and what they liked about it using verbs 
such as estar/ser (to be) and haber-hay (there is/are). This group had to submit their video in week 7 of the semester. Spanish 1 students from Sem I 2015 were required to record a video on their favourite restaurant consisting of a brief description of the restaurant and the food, and saying why they liked that restaurant. They had to submit their video in week 11 of the semester.

Given the pedagogical and physical difficulties in submitting the video in 2014, the steps were explained differently in 2015. Teachers were given the criteria and instructions on how to mark. If any doubts about how to mark arose then the coordinator viewed the video as well, discussed the mark with the teacher, assessed it and validated it.

\subsubsection{Data Collection}

A qualitative research approach was used in the data collection of this study. The researcher combined four instruments: (i) an on-line survey where the students answered open questions aimed at collecting qualitative data to report on the benefits of using mLearning (ii) classroom observations (iii) video samples and (iv) a semi-structured interview with the teachers, informal conversations and communication via email. The validity aspect of this research was achieved through undertaking methodological triangulation by using three instruments, i.e. questionnaires, interviews, and observations. Care was taken to during the administration of questionnaires, and use of video samples. Specifically, a consent form was developed based on the guidelines of RMIT University Human Research Ethics Committee (HREC). The consent form included an information sheet covering issues relating to anonymity, confidentiality, purpose of research, and the voluntary participation of the participants. All the participants received the consent form and information sheet in advance of their participation in the study.

(i) The survey was designed in light of the current theoretical perspectives on the implementation of mobile learning in foreign language contexts. The questions were developed to identify students' views on the benefits of mLearning and their use of it. The survey questions were not intended to obtain a numerical response but rather to focus on the content. For instance, the type of technology they use, where and how often they use it and the benefits of using mLearning for assessment purposes. The survey was sent out after the end of the semester so they did not feel obliged to complete it. Students were also informed that their participation was purely voluntary, there would be no penalties and it would not affect their academic results. The survey took approximately 15 minutes. 
(ii) Observations in class were recorded by each teacher and later discussed with the researcher. These observations merely recorded informal teacher/student, student/student conversations about the use of mLearning devices for learning Spanish.

(iii) The video samples submitted by students for assessment were stored securely on the researcher's RMIT computer and she was the only person with access to them.

(iv) An informal semi-structured interview was conducted with 4 teachers of Spanish 1 or Spanish 2. In order to triangulate the data resulting from the questionnaires and interviews, the interview questions were based on the same issues on which the questionnaires had been designed. For instance, observations in class, feedback on the students' oral proficiency, and teacher and student opinions about the whole experience of the assessment. This communication also took place via email.

\subsubsection{Data Analysis}

The researcher used an interpretative paradigm (qualitative research approach) by using content analysis in the responses to the survey, the teachers' interviews and observations in the class.

Keeping in mind the research questions regarding how students benefit, how they can become independent learners and how to motivate other teachers to use mLearning, the data were grouped under domains: (1) likes of the activity, (2) dislikes of the activity, (3) benefits: this domain was sub-grouped as follows: a) oral skills, b) written skills, c) vocabulary skills d) independence learning skills: these were also sub-grouped: a) extra activities not used in class, b) where do you use mLearning (e.g. home, car, tram), (5) improvements, and (6) ideas for other activities using smartphones.

The results of the survey, interviews and observations were then triangulated into one of the domains mentioned above in order to carry out a content analysis. In addition, the content of the questions was coded, categorized and synthesized from the domains until clear and definitive themes emerged.

The content analysis was conducted inductively on students' comments to find out how students use mobile devices outside of the classroom and what benefits could be derived from the use of mLearning. Video and evaluation criteria were also taken into consideration. 


\section{RESULTS}

\subsection{Research Question 1. How do students benefit from integrating mLearning into the Spanish language teaching activities?}

As Table 1 shows, the majority of students saw the cultural/oral activity in this study as innovative and a break from the usual assignments. Students also commented that this activity helped them to put the phrases and grammar learned into context by creating a biographic film and also to revise what they had learned in class. Results also showed that all students shot the video a number of times as they were conscious of their grammar mistakes and pronunciation and did not want to submit an unsatisfactory assessment. Students also stated that they had more than enough time to prepare and that they were able to record it as many times as needed. The majority of students also discovered that this activity allowed them to be creative, spontaneous and gave them the opportunity to use Spanish in an everyday life activity, which they felt was real and practical. Those students who were very engaged in the activity wanted to do other activities using mLearning as they found that it was a practical way to learn and to practice their oral skills. Some of these suggestions were: to record the teachers' pronunciation so they could hear it on the move (in the gym, car, tram, bike), pop-up quizzes sent by phone, Spanish games, to record Spanish conversation on various topics between two students.

\begin{tabular}{l|l}
\hline Benefits & Students' quotes \\
\hline Innovative & $\begin{array}{l}\text { "It was a creative assignment that got me outdoors and around } \\
\text { my neighbourhood and learn more about it." }\end{array}$ \\
\hline Oral & $\begin{array}{l}\text { "It encouraged interesting expression of a textbook topic, which } \\
\text { can be quite bland, and encouraged us to practice the language } \\
\text { orally without just reading something out." }\end{array}$ \\
\hline Written/Grammar & "Put the phrases into context by creating biographic film" \\
\hline Vocabulary/Pronunciation & $\begin{array}{l}\text { "I had to make sure I knew how to pronounce everything } \\
\text { properly because I had to listen to myself after I recorded it so I } \\
\text { could see where I went wrong." } \\
\text { "I wanted to be descriptive and insightful in my video so I tried } \\
\text { to use more interesting vocabulary, which meant that I had to } \\
\text { do a lot of translating and look things up." }\end{array}$ \\
\hline Real/Practical & $\begin{array}{l}\text { "I love the fact that I got a chance to use my Spanish, what I } \\
\text { have learnt, in my daily life. It felt real and practical. I feel like I } \\
\text { could speak to a native speaker about my neighbourhood. It is } \\
\text { an activity that's very empowering like that." }\end{array}$ \\
\hline
\end{tabular}

Table 1. Student comments about using mobile devices in their Spanish assessment 
Although students described the benefits of this assessment they also mentioned some of the problems encountered in submitting this assessment. These issues included frustration at the difficulties in uploading their video onto blackboard. Comments included: it took longer than expected, it was stressful as technical problems prevented submitting the assignment on time and it caused anxiety that a late submission might incur a penalty. Here are some of the remarks in terms of IT issues:

"Uploading it to Google Drive proved difficult when it came to submitting it. There
were a few issues and the video had to be handed to my teacher personally."
"I had a lot of trouble trying to upload it which wasted a lot of time and was very
frustrating! What was perhaps most frustrating was that there was no alternative
to uploading it, so if you didn't have easy access to technology or had
technological difficulties, you were disadvantaged."

Students were reassured that they would not be disadvantaged in any way if a late submission was due to technical problems.

\subsection{Research Question 2. How might these activities motivate student engagement and independent learning?}

Table 2 shows how students were encouraged to engage in the activity and create independent learning. The results also show students realise that to submit something worthwhile they needed to prepare quite stringently and that this means going out of their comfort zone in searching for new vocabulary and writing the dialogue more than once. Doing this enables them to express themselves more confidently in written Spanish. The results also highlight the empowerment and self-confidence students can attain in engaging in these sort of activities.

\begin{tabular}{l|l}
\hline Benefits & Students' quotes \\
\hline Engagement & $\begin{array}{l}\text { "I attempted to speak in standard Spanish and in a more } \\
\text { spontaneous manner, similarly to how I speak in my first } \\
\text { language." }\end{array}$ \\
\hline Independence & $\begin{array}{l}\text { "Because when I wanted to talk about my real, daily life, I } \\
\text { actually looked up for more words, I worked on trying to } \\
\text { improve what I wanted to say. I articulated my thoughts better, } \\
\text { rather than studying at home based on textbook with imaginary } \\
\text { characters, with only the vocab that the teacher provides." } \\
\text { "I wanted to tell the truth so I researched words I didn't know } \\
\text { yet." }\end{array}$ \\
\hline
\end{tabular}

Table 2. Students' engagement and independence 
\begin{tabular}{l|l}
\hline Confidence & "It was very practical and I felt like I could use and utilize my
\end{tabular} Spanish in my everyday life. I could speak in Spanish talking about my real life and I sent the video to my relatives overseas. It was very empowering to prepare my work that way."

Table 2. Students' engagement and independence (cont.)

5.3. Research Question 3. How might the use of mLearning activities motivate language educators to implement these activities in their classes?

Results based on the teacher interviews and email communication demonstrated that all four teachers welcomed this activity as something innovative and creative and something they could use effectively in their courses. Table 3 demonstrates the benefits this activity had on the student learning process as perceived by the teachers. In terms of language acquisition they considered it a great idea that students could do an oral assessment that allows repetition, and have the opportunity to have some intensive practice before the final oral exam. Teachers also remarked that an outside activity such as this allows students to prepare well for the assessment. All teachers remarked that it was easier for them to mark because it was short and also they could give a fair grade to the students as they could watch it as many times as needed. Teachers commented that all these positive results have motived them to continue implementing mLearning activities in their classes. However, some concern was expressed at the possibility of students memorizing the content. Two teachers felt that it was possible for students to memorize the script thus rendering the activity neither creative nor genuine. These teachers also had reservations about the possibility of some students using an online translator as it could disadvantage other students. All of the teachers were concerned about technological hitches. Every teacher had at least one student who had experienced technical problems and felt this was both time wasting and caused unnecessary anxiety. One teacher suggested showing a practice video in class to help students avoid technical problems and that the video could subsequently be uploaded for students to consult if they needed. A sample video of how to upload had in fact already been provided.

\begin{tabular}{l|l}
\hline Benefits & Teachers' quotes \\
\hline Engagement & "Students were engaged and worked hard in producing an \\
& $\begin{array}{l}\text { interesting video where they could showcase their oral skills. } \\
\text { The opportunity to be creative seemed to be very motivating." }\end{array}$ \\
\hline
\end{tabular}

Table 3. Teachers' engagement and motivation to use mLearning 


\begin{tabular}{l|l}
\hline Preparation/Repetition & $\begin{array}{l}\text { "In terms of content it gives students the opportunity to be } \\
\text { exposed to a diversity of restaurants and food due to } \\
\text { different cultures that co-exist in Melbourne." }\end{array}$ \\
\hline Marking & "It was very practical and easy to mark." \\
\hline
\end{tabular}

Table 3. Teachers' engagement and motivation to use mLearning (cont.)

\section{Discussion and conclusion}

This study presents the benefits that students and teachers found by using mLearning devices in the process of learning a second language (in this case Spanish). Students and teachers alike recognize how oral, grammar and vocabulary skills can be improved through the activities described in this article. As well as developing independent and confident learners, teachers are also motivated to be more involved in the implementation of mLearning activities as part of the continuing development of the Spanish curriculum at RMIT University.

These results are consistent with previous studies in the field of second language acquisition, demonstrating that mLearning allows foreign language students to improve vocabulary, grammar, listening and oral skills. Levy and Kennedy (2005) in their study on Japanese and Italian learners found that the use of SMS improved students' vocabulary; Gromik (2012) in his study on Japanese students of English found that the use of cell phones to make video recordings helped students to improve their oral skills; Liu's (2009) study on EFL Chinese learners found that PDAs (personal digital assistance) was useful for language speaking and listening learning. Liu's (2009) results were consistent with those of Myers (2005) who found that Chinese learners using PDA would repeatedly practice unfamiliar words and took written notes about new words and phrases. Gutiérrez-Colón Plana, Gimeno, Appel and Hopkins's (2015) results show that Spanish learners of English as a second language improved their reading skills by using WhatsApp.

One of the reasons mLearning activities assist in second language acquisition is because they allow for as much repetition as needed in the student's own time and place. This was also indicated in Myer's study (2005). Another important observation to emerge from this study is that students were so engaged in the activity that they put together some amazing videos obviously involving a lot of preparation and creativity, knowing full well that they were not worth that much in terms of marks. Students also stated that these activities allowed them to have spontaneous conversations, and to be 
conscious of their pronunciation and self-correct thus improving their communication skills.

Moreover, the use of mLearning in the Spanish class allows students to learn in a very independent, fun and engaging way. It also helps them to achieve the learning outcomes of the course such as communicating in both oral and written Spanish in a social context. They are able to evaluate their own language learning strategies, and to identify and discuss aspects of the Spanish culture, in some instances on their own, independent of a teacher.

The results of this study then demonstrate that students can achieve the ability to actively take charge of their own learning process by developing a selfindependent way of learning. In addition, their self-confidence is boosted and they acquire the positive attitude required to continuing learning the target language. This is consistent with various studies using mLearning devices (e.g. Attewell, 2005; Başoğl and Akdemir, 2010; Bull and Reid, 2004; Evans, 2008; Levy and Kennedy, 2005; Gromik, 2012; Gutiérrez-Colón Plana, Gimeno, Appel and Hopkins, 2015; Stockwell and Hubbard, 2013). More specifically, Attewell and Savill-Smith (2004) and Bull and Reid (2004) also found in their studies that the use of mLearning activities developed self-independent and promoted lifelong learning in the student. Daniel and Beckmann (2011) found that students learning Spanish in Australia became deeply engaged in their learning when using podcasting as it gave them flexible access to authentic listening material.

The aim of using smartphone video recording in this study was to improve all those skills already mentioned by the students and to develop an independent way of learning, but the increased confidence students gained was an unexpected bonus. This was a very positive outcome providing a strong foundation for beginner students to continue learning a language with high degree of confidence. A better attitude can only translate into better results. Similar results were found in Attewell's study (2005) with students from UK, Italy and Sweden using mLearning to learn a foreign language. She noted that students' self-esteem increased as they saw progress in their learning. This positive attitude towards learning English was also found by Başoğl and Akdemir in their study (2010).

The teachers involved in this study recognized the need and importance of using mLearning activities in the classroom as nowadays most students are familiar with the use of mobile devices starting from primary school. All teachers welcomed the idea of the smartphone activity and even indicated that in the future cultural differences could be explored when students do 
their presentation on food and restaurants. Teachers also remarked that these sorts of assessments are creative, relate to real things in the students' lives, allow repetition, are good practice for the final oral exam, and are effective in making students prepare well for an assessment.

By actually witnessing the benefits that mLearning devices bring to the process of learning a second language teachers are motivated to use mLearning activities in classes. Understanding that technology does not pose a threat to their teaching or their job as a teacher is important. On the contrary it provides more resources for the implementation of new ideas that could not be achieved without the support of technology. As Higgins, Beauchamp and Miller (2007) state "[G]good teaching remains good teaching with or without the technology" (p. 215). However, nowadays in a digital age it is important to keep up with students' interests and new ways of learning, and to make sure they are engaged in the learning process. As Stockwell's (2012) proposes "our goal as teachers is to gain an understanding as quickly as possible of the expectations of our learners, and to move with the times, adapting to the environment of now while keeping a keen eye on the environment of the future for our upcoming students of years to come" (p. 30).

It is also important to state that teachers and students cannot assume that one person is better than the other as "there is a tendency to assume that existing personal uses will transfer seamlessly to educational uses" (Stockwell and Hubbard, 2013, p. 6), or that one generation is more knowledgeable than the other in terms of technology (digital natives vs. digital immigrants). As Hockly (2011) states "we should not expect all of our younger learners to be digitally literate, and conversely, we should not assume our older learners are digitally illiterate." (p. 324). However, it is important that the teacher as a provider knows why, what and how to use it by not losing sight of pedagogical principles while applying the mobile principles.

Unfortunately, there were IT difficulties for some students during the submission of this assessment. Problems occurred despite the provision of step-by-step instructions of how to upload and students suffered frustration and stress. This is nothing new when using mLearning devices but the problem should not be ignored and allowed to continue, particularly as one of the objectives of the institution is to implement online activities and innovative ways of learning. Therefore, more support should be provided to those teachers who are willing to use technology. These technological problems have already been raised by various scholars who indicate that "other (physical issues) such as storage capacity, processor speed, battery life, and compatibility of devices (in terms of both operating systems and transfer of 
large amounts of data) have also been raised as points needing consideration in implementing mobile devices in learning contexts" (Stockwell and Hubbard, 2013 , p. 3). However, this drawback should not stop teachers and institutions from applying mobile teaching in their language programs.

\section{Recommendations}

One recommendation resulting from this study is the need to provide strong support to enable teachers to participate in digital workshops for the development of their knowledge and skills in the use of digital media, technology and mLearning. This will benefit both student learning and the development of the curriculum. As George-Walker and Keefe (2010) argue "through effective facilitation, instructors can support students in understanding what it is they are expected to learn, the choices they have available to them when learning and can assist them to develop the necessary skills of reflection, self-direction and self-management" (p. 3).

It is also recognised and recommended that further research should consider students' creativity and implement peer feedback videos. Studies have demonstrated that peer feedback helps them to be more aware of their mistakes, learn strategies for error correction and is beneficial to their learning (Lee and Markey 2014; Ware and O'Down, 2008).

With regard to technical or physical issues it is important to synchronise all operating systems on time with the support of the institution, to carry out several tests, and, in order to avoid students becoming anxious, to inform them before submission that should they encounter any technical problems (which sometimes are unavoidable), their marks will not be affected.

\section{About the authors}

Dr. Glenda Mejía is a Senior Lecturer at RMIT University, and the Coordinator of the Spanish Studies Program. Her research interests include: women studies (intersectionality), Latin American Cinemas (migration and borders in Mexican cinema), pedagogy (teaching and practice), language and identity, and Spanish-speaking migration in Australia. Her latest article is (2015) Intermarriage, Language Usage and Culture Maintenance: A Study of Spanishspeaking Immigrant Mothers in Australia, Journal of Multilingual and Multicultural Development http://www.tandfonline.com/eprint/ZbkX3cVNrerzxgR5mFXi/full 


\section{Article history}

Paper received: $09^{\text {th }}$ February 2016

Paper received in revised form and accepted for publication: $17^{\text {th }}$ April 2016

\section{REFERENCES}

Ally, M. (2013). Mobile learning: From research to practice to impact education. Learning and Teaching in Higher Education: Gulf Perspectives, 10(2), 1-10. <http://lthe.zu.ac.ae/index.php/Ithehome/article/viewFile/140/62> [12-03-16]

Attewell, J., \& Savill-Smith, C. (2004). Mobile learning and social inclusion: Focusing on learners and learning. In J. Attewell \& C. Savill-Smith (Eds.), Learning with mobile devices: Research and development (pp. 3-11). London, UK: Learning Skills and Development Agency.

Attewell, J. (2005). Mobile technologies and learning: A technology update and m-learning project summary. London, UK: Learning Skills Development Agency. <http://www.mlearning.org/doc/The m-learning project - technology update and20project\%summary.pdf> [10/11/2014]

Başoğl, E. B., \& Akdemir, Ő. (2010). A comparison of undergraduate students' English vocabulary learning: Using mobile phones and flash cards. The Turkish Online Journal of Educational Technology, 9, 1-7.

Bastarrechea, J. P. (2003). El aula virtual de español. Un proyecto del Instituto Cervantes para integrar el potencial de las nuevas tecnologías de la informacón y la comunicación en la actividad docente. II Congreso Internacional de Español para Fines Específicos. II CIEFE. $<$ http://cvc.cervantes.es/ensenanza/biblioteca_ele/publicaciones_centros/PDF/tokio_2013 /21_navarro.pdf> [11-04-2016]

Bennet, S., Maton, K., \& Kervin, L. (2008). The "digital natives" debate: a critical review of the evidence. British Journal of Educational Technology, 39 (5), 775-86. http://tinyurl.com/ycrklnq [10/08/2015]

Bull, S., \& Reid, E. (2004). Individualised revision material for use on a handheld computer. In J. Attewell, \& C. Savill-Smith (Eds.), Learning with mobile devices: Research and development (pp. 35-42). London, UK: Learning Skills and Development Agency.

Chang, Y., Wu, C., \& Ku, H. (2004). The introduction of electronic porfolios to teach and assess English as a Foreign Language in Taiwan. TechTrends, 49(1), 30-35.

Dieterle, E., Dede, C., \& Schrier, K. (2007). Neomillennial' learning styles propagated by wireless handheld devices. In M. Lytras \& A. Naeve (Eds.), Ubiquitous and pervasive knowledge and learning management: Semantics, social networking and new media to their full potential (pp. 35-66). Hershey, PA: Idea Group. 
Evans, C. (2008). The effectiveness of m-learning in the form of podcast revision lecturers in higher education. Computers \& Education, 50(2), 491-498.

Garrison, D.R. \& Vaughan, N.D. (2008). Blended learning in higher education: Framework, principles, and guidelines. San Francisco: John Wiley \& Sons.

George-Walker, L. \& Keefe, M. (2010). Self-determined blended learning: a case study of blended learning design. Higher Education Research and Development, 29, 1-13.

Gromik, N. (2012). Cell phone video recording feature as a language learning tool: A case study. Computers \& Education, 58(1), 223-230.

Gutiérrez-Colón Plana, M., Gimeno, A., Appel, C., \& Hopkins, J. (2015). Improving learners' reading skills through instant short messages: A sample study using WhatsApp. In A. Gimeno-Sanz, M. Levy, F. Blin, F. \& D. Barr, (Eds.), WordICALL Sustainability and ComputerAssisted Language Learning (pp. 266-84). London: Bloomsbury.

Higgins, S., Beauchamp, G., \& Miller, D. (2007). Reviewing the literature on interactive whiteboards. Learning, Media and Technology, 32, 213-225.

Hockly. N. (2011). The digital generation. ELT Journal, 65(3), 322-325. <http://eltj.oxfordjournals.org/content/65/3.toc> [10/08/2015]

Honebein, P. C., Duffy, T. M., \& Fishman, B. J. (1993). Constructivism and the design of learning environments: Context and authentic activities for learning. In T. M. Duffy, J. Lowyck \& D. H. Johassen (Eds.), Designing environments for constructive learning (pp. 87-108). Heidelberg: Springer-Verlag.

Kadirire, J. (2009). Mobile learning demystified. In R. Guy (Ed.), The evolution of mobile teaching and learning (pp. 15-55). Santa Rosa, CA: Informing Science Press.

Levy, M. \& Kennedy, C. (2005). Learning Italian via mobile SMS. In A. Kukulshka-Hulme \& J. Traxler (Eds.), Mobile learning: A handbook for educators and trainers, (pp. 76-83). London: Routledge.

Lee, L., \& Markey, A. (2014). A study of learners' perceptions of online intercultural exchange through Wed 2.0 technologies. ReCALL, 26(3), 1-20.

Liu, T.-Y. (2009). A context-aware ubiquitous learning environment for language listening and speaking. Journal of Computer Assisted Learning, 25(6), 515-527.

Losada, A. (2005). Las nuevas tecnologías y la enseñanza-aprendizaje del español lengua extranjera. In M. Cal Valera (Coord.), Nuevas tecnologías en linguística, traducción y enseñanza de lenguas (pp. 181-202). Santiago de Compostela: Servicio de publicaciones de la Universidad de Santiago de Compostela.

Martin, D., \& Beckmann, E. A. (2011). Simulating immersion: Podcasting in Spanish Teaching. In B. R. Facer \& M. Abdous (Eds.), Academic podcasting and mobile assisted language learning: Applications and outcomes (pp. 111-131). New York: Information Science Reference. 
Motiwalla, L. F. (2007). Mobile learning: A framework and evaluation. Computers \& Education, 49, 581-596.

Naismith, L., Lonsdale, P., Vavoula, G., \& Sharples, M. (2004). report 11: literature review in mobile technologies and learning. Futurelab: Bristol.

Navarro, P. (2013). the spanish virtual classroom (Aula Virtual de Español, AVE) as an example of introduction of new technologies in the class of Spanish as a foreign language. In Actas del congreso internacional sobre el español y la cultura hispánica. instituto cervantes de tokio. <http://cvc.cervantes.es/ensenanza/biblioteca_ele/publicaciones_centros/PDF/tokio_2013 /21_navarro.pdf> [11-04-2016]

Picciano, A. G. (2009). Blending with purpose: The multimodal model. Journal of Asynchronous Learning Networks, 13(1), 7-18.

Picciano, A. G. (2016). Research in online and blended learning. New challenging, new opportunities. In C. Dziuban, A. G. Picciano, C. R. Graham \& P. D. Moskal (Eds.), Conducting research in online and blended learning environments: New pedagogical frontiers (pp. 1-11). New York: Routledge/Taylor \& Francis.

Prensky, M. (2001). Digital natives, digital immigrants Part 1. On the Horizon, 9(5), 3-6.< http://tinyurl.com/ypgvf> [10/08/2015]

Prensky, M. (2009). H. sapiens digital: from digital immigrants and digital natives to digital wisdom. Innovate: Journal of Online Education, 5(3), 1. <http://nsuworks.nova.edu/ innovate/vol5/iss3/1> [10/08/2015]

Sharples, M., Corlett, D., \& Westmancott, O. (2002). The design and implementation of a mobile learning resource. Personal and Ubiquitous Computing, 6(3), 219-234.

Stead, G. (2005). Moving mobile into the mainstream. In Proceedings of mLearn 2005 (pp. 1-9). <http://www.mlearn.org.za/papers-full.html> [10/08/2015]

Stockwell, G. (2012). Commentary: Working with constraints in mobile learning: A response to Ballance. Language Learning \& Technology, 16(3), 24-31.

Stockwell, G. (2013). Tracking learner usage of mobile phones for language learning outside of the classroom. In P. Hubbard, M. Schulz \& B. smith (Eds.), Learner-computer interaction in language education: A festschrift in honor of Robert Fischer (pp.118-136). San Marcos, TX: CALICO.

Stockwell, G., \& Hubbard, P. (2013). Some emerging principles for mobile-assisted language learning. Monterey, CA: The International Research Foundation for English Language Education.<http://www.tirfonline.org/english-in-the-workforce/mobile-assisted-languagelearning> [10-11-14]

Sykes, J. M. (2005). Synchronous chat and pragmatic development: Effects of oral and written chat. CALICO Journal, 22, 399-431.

Tozcu, A. (2008). The use of interactive whiteboards in teaching non-roman scripts. Computer Assisted Language Learning, 21, 143-166. 
Ware, P., \& O'Dowd, R. (2008). Peer feedback on language form in telecollaboration. Language Learning \& Technology, 12(1), 43-63.

Williamson, B., \& Hague, C. (2009). Digital participation, digital literacy and school subjects: A review of the politics, literature and evidence. Bristol: Futurelab. $<$ http://tinyurl.com/5wkhfeb> [10/08/2015] 